\title{
PERAN DAN IMPLEMENTASI HUKUM DALAM MEMBERIKAN KEPASTIAN JAMINAN SOSIAL BAGI PEKERJA SEKTOR INFORMAL
}

\author{
Wandi Subroto \\ Sekolah Tinggi Ilmu Hukum Rahmaniyah Sekayu, Indonesia \\ Email: wandi.stihr@gmail.com
}

\begin{abstract}
Abstrak
Tujuan penelitian ini adalah untuk menganalisis peran serta implementasi hukum dalam memberikan kepastian jaminan sosial bagi pekerja sektor informal. Penelitian ini menggunakan motode yuridis-normatif. Jenis sumber hukum yang digunakan dalam penelitian ini adalah sumber hukum sekunder yang dibahas menggunakan perspektif sosiologis. Analisis dan penulisan dilakukan dengan metode kualitataif. Pengumpulan data dilakukan melalui teknik wawancara, pemberian kuisioner, dan studi literatur. Jumlah responden dalam penelitian ini adalah 50 orang yang bekerja dalam sektor informal di Kota Palembang. Pemilihan responden dilakukan dengan teknik purposive sampling. Berdasarkan analisis bahan hukum dan analisis sosiologi, dapat disimpulkan bahwa hukum melindungi kesejahteraan sosial melalui Undang-Undang Nomor 40 tahun 2004 menyatakan bahwa Sistem Jaminan Sosial Nasional menganut prinsip kepesertaan wajib bagi seluruh penduduk di Indonesia. Dalam implementasi kebijakan ini, sektor informal masih mengalami beberapa kendala diantaranya adalah karena faktor pendidikan, faktor ekonomi dan faktor kelembagaan sehingga tingkat partisipasi pekerja cenderung minim dan belum terjadi pemerataan.
\end{abstract}

Kata Kunci: Jaminan Sosial, Hukum, Sektor Informal.

\begin{abstract}
The purpose of this study is to analyze the role and implementation of the law in providing social security certainty for informal sector workers. This study uses a juridical-normative method. The types of legal sources used in this study are secondary sources of law which are discussed using a sociological perspective. The analysis and writing was done by qualitative method. Data was collected through interview techniques, giving questionnaires, and literature studies. The number of respondents in this study were 50 people who worked in the informal sector in the city of Palembang. The selection of respondents was done by purposive sampling technique. Based on the analysis of legal materials and sociological analysis, it can be concluded that the law protects social welfare through Law no. 40 of 2004 states that the National Social Security System adheres to the principle of compulsory participation for all residents in Indonesia. In the implementation of this policy, the informal sector is still experiencing several obstacles, including educational factors, economic factors and institutional factors so that the level of worker participation tends to be minimal and there is no equal distribution.
\end{abstract}

Keywords: Social Security, Law, Informal Sector. 


\section{A. PENDAHULUAN}

Pemerintah Indonesia telah menjamin jaminan sosial bagi seluruh warga negara melalui penetapan UU Nomor 40 tahun 2004 tentang Sistem Jaminan Sosial Nasional yang selanjutnya disebut dengan SJSN. Tujuan dirumuskan SJSN adalah agar pekerja beserta keluarganya terlindungi dari kecelakaan, kematian, dan sakit (Sholihah \& Sabarisman, 2018). Pelaksanaan SJSN tahap pertama mencakup seluruh pekerja sektor formal dan dilanjutkan ke tahap berikutnya, yaitu untuk pekerja sektor informal seperti nelayan, petani, dan pengusaha. Untuk mencapai tujuan tersebut, Pemerintah membentuk badan usaha tersendiri yang diberi nama BPJS Ketenagakerjaan, satu-satunya badan penyelenggara jaminan sosial bagi pekerja di Indonesia (Arliman, 2017).

Pada tahun 1992, Pemerintah menetapkan Undang-Undang Nomor 3 Tahun 1992 tentang Jaminan Sosial Tenaga Kerja. Melalui Peraturan Pemerintah No.36 Tahun 1995, Pemerintah menetapkan PT Jamsostek sebagai Badan Penyelenggara Jaminan Sosial Ketenagakerjaan. Selanjutnya, pada tahun 2011, Pemerintah memberlakukan UndangUndang Nomor 24 Tahun 2011 tentang Badan Penyelenggara Jaminan Sosial (BPJS). Sebagaimana diatur dalam Undang-Undang, pada 1 Januari 2014, PT Jamsostek berubah menjadi badan hukum publik dan berubah menjadi BPJS Ketenagakerjaan dan beroperasi penuh pada 1 Juli 2015 (Widiyastuti, 2019). BPJS Ketenagakerjaan ditunjuk oleh Pemerintah untuk menyelenggarakan program jaminan sosial tenaga kerja, yang meliputi Jaminan Kecelakaan Kerja (JKK), Jaminan Hari Tua (JHT), Jaminan Pensiun, dan Jaminan Kematian menurut UU SJSN.

Kesejahteraan sosial masyarakat Indonesia diberikan oleh skema kebijakan dari program jaminan sosial. Program ini diharapkan dapat membuat warga negara dapat memenuhi kebutuhan dasar mereka untuk melindungi kerugian mereka di masa depan (Farah \& Yunanto, 2016). Pemerintah Indonesia sebagai juru kunci memastikan program berjalan sesuai rencana mengatur program semacam ini. Sesuai dengan Amandemen UUD 1945, Pemerintah pusat berkewajiban memberikan perlindungan sosial dan ekonomi kepada rakyat Indonesia (Pulungan, 2016). Sebagai bagian dari pelaksanaan amanat konstitusi, Pemerintah Indonesia mengembangkan program jaminan sosial berbasis jaminan sosial yang didanai negara. Program jaminan sosial dilaksanakan bersama PT Jamsostek, yang kemudian berganti nama menjadi BPJS Ketenagakerjaan.

Menurut undang-undang, Perusahaan wajib mendaftarkan semua pekerjanya ke SJSN. Pekerja membayar premi berdasarkan persentase pendapatannya kepada perusahaan, dan kemudian perusahaan mentransfer uang tersebut ke BPJS Ketenagakerjaan. Salah satu cara yang digunakan BPJS Ketenagakerjaan untuk memastikan bahwa perusahaan mematuhi hukum adalah dengan melakukan investigasi rutin atau langsung (Priesteta et al., 2019). Investigasi tunduk pada seluruh perusahaan yang telah dilisensikan dan diizinkan untuk melakukan bisnis mereka dari pemerintah. Jika ketahuan tidak mendaftar atau tidak membayar premi, Perusahaan dapat didenda sejumlah besar uang. Investasi dana BPJS Tenaga Kerja disajikan dalam gambar berikut: 


\section{Penyaluran Dana BPJS TK}

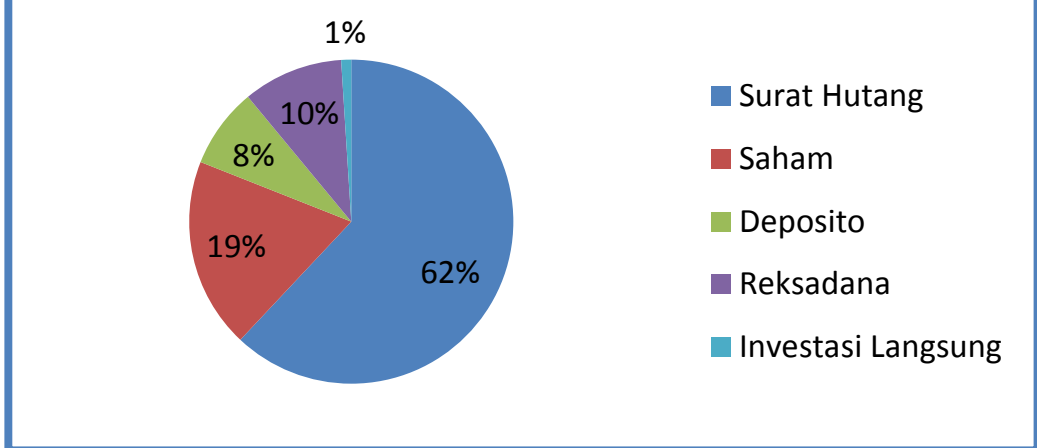

\section{Gambar 1. Penyaluran Dana Kelola BPJS TK}

Sumber: Data Diolah

Hingga pertengahan Juli 2018, BPJS Ketanakerjaan tercatat mengumpulkan dana sebasnyak Rp. 333 triliun, lebih banyak 15\% dari dana terkumpul tahun sebelumnya. Pengembangan aset BPJS Ketenagakerjaan harus sesuai dengan PP No. 5/2015 dan PP No. 99/2013. Lebih lanjut, UU No. 40/2004 tentang SJSN merupakan undang-undang kerangka kerja.3 UU tersebut tidak mengatur secara rinci manfaat dan tingkat iuran untuk setiap program; melainkan menguraikan struktur dasar sistem jaminan sosial yang direformasi, diantaranya adalah: 1) Cakupan luas untuk semua warga negara Indonesia, baik untuk pekerja formal maupun informal dan tanggungan mereka, yang akan diminta untuk memberikan kontribusi pada program; 2) Lima program terpisah akan dibuat dalam sistem; 3) Empat perusahaan jaminan sosial milik negara - JAMSOSTEK, ASKES, TASPEN dan ASABRI akan bertindak sebagai pengelola program; 4) Dewan Jaminan Sosial Nasional akan dibentuk dengan 15 anggota yang mewakili pemerintah, pengusaha, pekerja dan tenaga ahli; 5) Pekerja formal dan informal akan memberikan kontribusi yang berbeda. Kontribusi pekerja formal sebagai persentase dari upah dan dibagi antara pekerja dan pengusaha. Bagi pekerja informal, iuran dalam jumlah nominal dalam rupiah; dan 6) Pemerintah akan membayar iuran masyarakat miskin (Thoriq, 2018).

Menurut Peraturan Pemerintah Nomor 44, 45, dan 60 Tahun 2015, BPJS Ketenagakerjaan berwenang memeriksa, memenjarakan, dan mengenakan denda kepada perusahaan yang tidak mendaftarkan pekerjanya secara penuh atau tidak membayar iuran. Juga dalam Peraturan Pemerintah Nomor 86 Tahun 2013 tentang Pengenaan Sanksi Administratif Kepada Pegawai, Pekerja, dan Penerima Jaminan Sosial (Widodo \& Galang, 2019). Yang dimaksud dengan pekerja terdaftar adalah setiap orang yang bekerja di Indonesia sekurang-kurangnya enam bulan; Perusahaan wajib mendaftarkan seluruh pekerjanya sesuai dengan skema jaminan sosial yang didaftarkannya. BPJS Ketenagakerjaan memiliki spesialisasi rekrutmen pegawai yang akan melaksanakan tugas penyidikan (Riwanto \& Gumbira, 2017). Selain itu, BPJS Ketenagakerjaan telah bekerja sama dengan kejaksaan setempat untuk mengumpulkan iuran yang belum dibayar, denda, atau masalah hukum lainnya.

UU SJSN menetapkan 5 program jaminan social yaitu: pension, tabungan hari tua, manfaat terkait kesehatan, santunan kecelakaan kerja, dan dana hibah kematian. Namun, rincian mengenai tingkat manfaat dan biaya diserahkan kepada peraturan pemerintah dan 
keputusan presiden. Mengenai pengaturan kelembagaan, UU SJSN mengatur bahwa empat perusahaan jaminan sosial milik negara yang ada akan membentuk BPJS. Namun, peran yang tepat dari masing-masing lembaga itu akan ditentukan dalam undang-undang tersendiri. Secara umum kegiatan usaha BPJS Ketenagakerjaan terdiri dari 1) Menerima pendaftaran peserta dan pengelolaan data kepesertaan; b) Menerima iuran kepesertaan dan pembayaran manfaat melalui penyelenggaraan program jaminan sosial; c) Pengelolaan Dana Jaminan Sosial; dan d) Mengelola dan mendistribusikan fasilitas kesejahteraan peserta. Sasaran BPJS Ketenagakerjaan adalah meningkatkan kepesertaan aktif dari 16,8 juta pekerja pada tahun 2014 menjadi 45,6 juta pekerja pada tahun 2018, serta meningkatkan fungsi penegakan hukum pada tingkat kepesertaan untuk meningkatkan kepatuhan peserta menjadi $80 \%$ pada tahun 2018.

Adanya regulasi ini sangat penting bagi kehidupan masyarakat secara luas, namun masih terdapat banyak permasalahan yang menghambat tujuan kesejahteraan tersebut (Susanto \& Iqbal, 2019). Herry Jogaswara sebagai kepala Pusat Penelitian Kependudukan LIPI mengatakan bahwa masalah tersebut banyak menyangkut penyerapan program masyarakat yang bekerja dalam sektor informal. Padahal sebanyak 57\% penduduk Indonesia justru melakukan aktifitas ekonomi yang bergerak dalam sektor informal menurut Survei AKN (Angkatan Kerja Nasional) pada tahun 2018. Hal ini sangat penting untuk diperhatikan oleh pemangku kebijakan karena masyarakat yang bekerja dalam sektor informal memiliki legalitas dan upah harian yang relatif rendah dibandingkan masyarakat yang bekerja dalam sektor formal. Menurut Herry Jogaswara hal ini disebabkan oleh mininmya tingkat pengetahuan masyarakat tentang manfaat positif dari jaminan sosial sebagai faktor ketidakikutsertaan pelaku ekonomi informal ini. Perbandingan jumlah pekerja formal dan informal dari tahun 2012-2019 disajikan dalam tabel berikut:

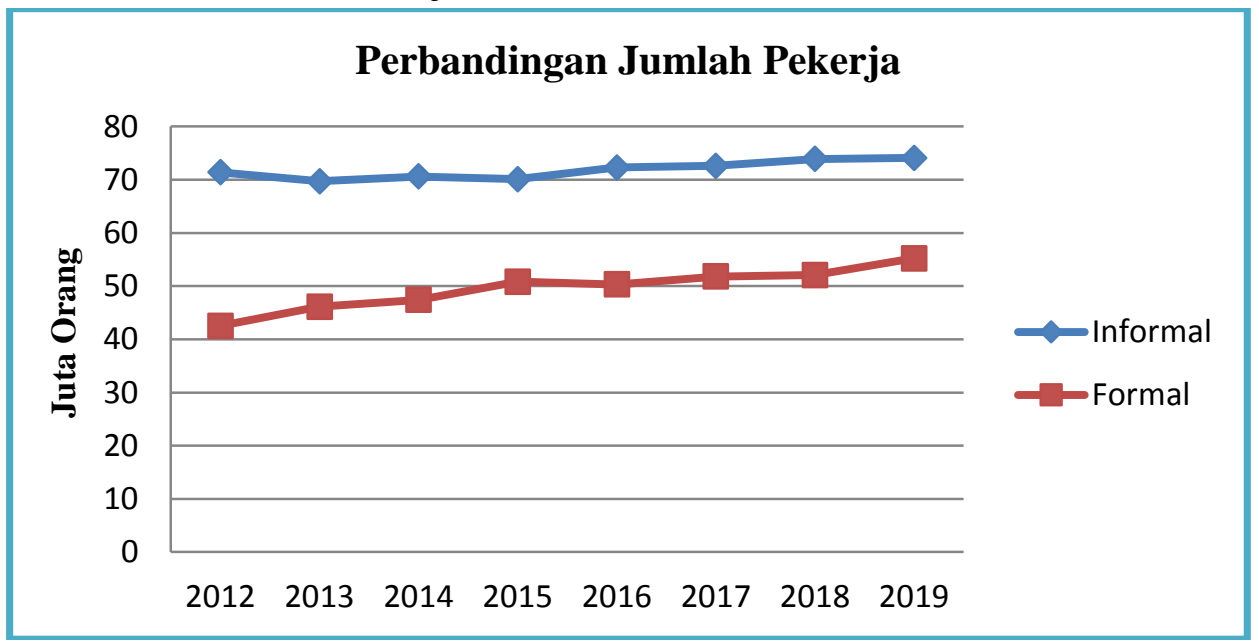

\section{Gambar 2. Perbandingan Jumlah Pekerja Formal dan Informal (Periode 2012-2019)}

Sumber: Lokadata (Februari 2019)

Berdasarkan data tersebut, dapat diketahui bahwa terdapat perbedaan mencolok antara jumlah pekeraj formal dan informal di Indonesia dalam kurun waktu 8 tahun terakhir. Jumlah pekerja formal sebanyak lebih dari 55,2 juta pekerja, atau meningkat sebanyak 4,1 persen dari tahun 2018 (53 juta jiwa). Pada saat yang sama di sektor informal, jumlah pekerja telah mencapai 74,09 juta jiwa atau meningkat sebanyak 0,16 persen dari tahun 2018. Status pekerjaa informal ini terdiri dari: 1) usaha sendiri; 2) usaha yang dibantu oleh butuh tidak 
dibayar; 3) pekerja lepas dalam sektor pertanian; 4) pekerja lepas dalam sektor nnonpertanan; serta 5) pekerja tak dibayar. Karena tinggnya jumlah pekerja dalam sektor ini, maka kepastian jaminan sosial bagi pekerja sektor informal perlu ditinjau kembali (Madya \& Nurwahyuni, 2019).

\section{B. METODE}

Penelitian ini menggunakan motode yuridis-normatif. Jenis sumber hukum yang digunakan dalam penelitian ini adalah sumber hukum sekunder yang dibahas menggunakan perspektif sosiologis (Farianto et al., 2018). Analisis dan penulisan dilakukan dengan metode kualitataif. Dengan terlebih dahulu menjelaskan tentang jaminan konstitusi ata hak sosial dan ekonomi, lalu faktor penghambat dalam implementasi program yang telah direncanakan dan peran serta implementasi hukum dalam memberikan kepastian jaminan sosial (Zusmelia et al., 2019). Pengumpulan data dilakukan melalui teknik wawancara, pemberian kuisioner, dan studi literatur. Jumlah responden dalam penelitian ini adalah 50 orang yang bekerja dalam sektor informal di Kota Palembang. Pemilihan responden dilakukan dengan teknik purposive sampling.

\section{HASIL DAN PEMBAHASAN}

\section{Jaminan Konstitusi atas Hak Sosial dan Ekonomi bagi Warga Negara}

Amandemen Kedua menjamin hak-hak sosial-ekonomi seluruh warga negara. Namun ketentuan hak Sosial Ekonomi dalam UUD yang baru ini cukup terbatas. Amandemen Kedua hanya mengatur satu ketentuan utama tentang hak sosial ekonomi dalam Pasal $28 \mathrm{H}$, yang meliputi hak atas tempat tinggal, lingkungan yang sehat, perawatan kesehatan, dan hak atas jaminan sosial. Selain itu, Amandemen Keempat, pada tahun 2002, menetapkan bahwa setiap warga negara berhak atas pendidikan dan diperlukan anggaran pendidikan sebesar $20 \%$ dari anggaran nasional. Ada perbedaan yang cukup kontras antara Amandemen Kedua Indonesia dan Deklarasi Universal Hak Asasi Manusia (DUHAM). Dalam DUHAM, setidaknya ada enam ketentuan yang secara tegas menjamin hak sosial ekonomi, termasuk hak atas pangan, sandang, papan, perawatan kesehatan, pendidikan, dan waktu luang. Ketentuan hak-hak sosial ekonomi dalam Konstitusi Indonesia tidak selengkap DUHAM (Jatmiko, 2018; Strijobosch, 2019).

Bagian dari ketentuan konstitusi yang terkait dengan perdebatan hak sosial ekonomi tertuang dalam Pasal 33 tentang klausul ekonomi. Pasal 33 mengatur beberapa hal, diantaranya: (1) perekonomian disusun sebagai usaha bersama berdasarkan asas kekeluargaan; (2) Cabang-cabang produksi yang penting bagi negara dan yang mempengaruhi kesejahteraan umum dikuasai oleh negara; dan (3) bumi dan air serta kekayaan alam yang terkandung di dalamnya dikuasai oleh negara dan dipergunakan untuk sebesar-besar kemakmuran rakyat. Proses reformasi konstitusi tidak meninggalkan versi asli Pasal 33 tetapi juga menambahkan ketentuan baru yang menyatakan bahwa penyelenggaraan perekonomian nasional diselenggarakan berdasarkan demokrasi ekonomi dengan menjunjung tinggi prinsip kebersamaan, efisiensi berkeadilan, berkelanjutan, berwawasan lingkungan, kemandirian, serta menjaga keseimbangan kemajuan dan kesatuan perekonomian nasional (Jung, 2016). 
Pasal 33 tidak seharusnya menjadi bagian dari pemberian hak Sosial Ekonomi. Namun, dalam kenyataannya, Mahkamah seringkali menyamakan pengertian hak sosial ekonomi dengan penguasaan negara atas sumber daya alam berdasarkan Pasal 33. Alih-alih mendefinisikan hak-hak sosial-ekonomi sebagai hak individu, Mahkamah secara konsisten memberikan hak istimewa kepada negara untuk menguasai sumber daya alam atas nama melindungi hak-hak sosial-ekonomi. Selain itu, Mahkamah sangat mengandalkan gagasan tentang kewajiban negara untuk memenuhi hak warga negara. Pengadilan berulang kali memutuskan bahwa negara harus memenuhi hak-hak sosial ekonomi. Namun, Pengadilan jarang menjunjung hak sosial-ekonomi sebagai hak positif, yang memberikan hak kepada pemegang hak untuk menuntut agar penikmatan hak-hak tersebut dijamin. Singkatnya, Pengadilan sering menafsirkan ketentuan sosial-ekonomi dengan unsur komunitarian, yang menekankan negara berperan untuk memastikan warga negara mendapat hak-hak mereka.

Hanya dalam waktu empat bulan setelah berlakunya SJSN, UU tersebut digugat di Mahkamah Konstitusi. Dalam kasus SJSN I, beberapa pengelola Badan Penyelenggara Jaminan Sosial (BPJS) tingkat provinsi menggugat ketentuan pemerintah untuk membentuk Badan Penyelenggara Jaminan Sosial (BPJS). Mereka tidak mengangkat hak atas jaminan sosial, melainkan membingkai argumen mereka dalam relasi antara pemerintah pusat dan daerah. Para penggugat mendalilkan UU SJSN melanggar konstitusi karena memberikan kewenangan kepada pemerintah pusat untuk mengatur masalah jaminan sosial. Akibatnya, mereka berpendapat bahwa masalah jaminan sosial harus berada di bawah yurisdiksi pemerintah daerah, bukan pemerintah pusat. Menariknya, pemerintah pusat menggunakan hak atas jaminan sosial (pasal 28H) sebagai justifikasi pendirian BPJS.

MK telah memberikan kontribusi yang signifikan terhadap proses demokrasi di Indonesia dengan memberikan jalan bagi warga negara untuk membela hak-hak mereka. Namun demikian, MK belum berhasil melakukan kajian yang berarti atas hak-hak sosial ekonomi. Keputusan Pengadilan dalam rangkaian kasus hak atas jaminan sosial menunjukkan kegagalan Pengadilan untuk melakukan penilaian yang berarti atas hak-hak sosial ekonomi. Sebagian masalahnya adalah bahwa Pengadilan telah gagal mengakui sifat horizontal hak sosial-ekonomi, terutama hak atas jaminan sosial (Dartanto et al., 2019). Tidak semua sumber penindasan dan ancaman terhadap kebebasan individu berasal dari pemerintah. Kepentingan pribadi yang kuat juga mempengaruhi kebebasan individu. Dalam konteks hak atas jaminan sosial, Mahkamah tidak dapat membayangkan bahwa hak atas jaminan sosial juga dimaksudkan untuk melindungi atau menciptakan hak yang berlawanan dengan aktor nonpemerintah. Padahal MK hanya menetapkan mandat kepada pemerintah untuk mengembangkan program jaminan sosial. Selain itu, hak atas jaminan sosial mencakup hak untuk mengakses dan mempertahankan manfaat, baik dalam bentuk uang maupun barang. Di bawah pengaturan saat ini, Pengadilan gagal untuk beralih dari perumusan jaminan sosial terkait pekerjaan tradisional ke penyertaan penyebab kemiskinan yang lebih luas, terutama bagi jutaan pekerja yang tidak memiliki akses ke pekerjaan formal. Dengan demikian, mereka tidak memiliki akses ke asuransi sosial yang disponsori pemerintah. 


\section{Faktor Penghambat Jaminan Sosial bagi Warga Negara yang Bekerja dalam Sektor Informal}

Banyaknya jumlah pekerja yang bergerak dalam sektor informal, yaitu sektor ekonomi yang bergerak secara mandiri dan dalam skala yang kecil serta memiliki kebebasan ynag tinggi tentu sangat membantu perekonomian masyarakat secara luas. Hampir separuh dari penduduk Indonesia memenuhi kebutuhan ekonomi keluarganya dengan sektor tersebut. Namun hal ini belum diimbangi dengan pendampingan jaminan sosial yang efektif dari pemerintah. Hasil temuan penelitian yang dilakukan oleh Deputi Ilmu Pengetahuan Sosial dan Kebudayaan LIPI menemukan bahwa minimnya pekerja informal yang masuk dalam proteksi sosial negara tentu menghambat proses kesejahteraan sosial itu sendiri, program kesejahteraan tersebut harus didukung oleh jaminan ketenagakerjaan dan jaminan kesehatan. SJSN untuk sektor ketanagakerjaan informal baru tercapai tiga persen dari sepuluh persen yang dianggarkan. Hal ini disinyalir akibat dari minimnya kualitas layanan sehingga permintaan keikutsertaan dari sektor informal sangat minim. Hasil survei LIPI tentang aspek jaminan sosial dalam sektor informal disajikan dalam gambar berikut:

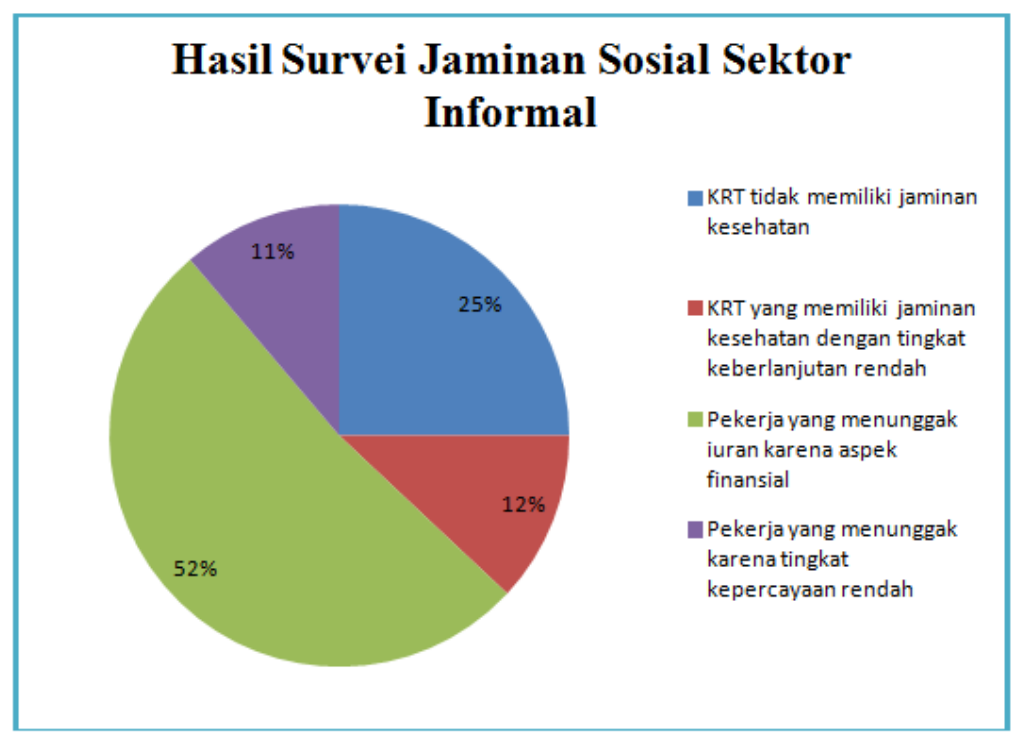

\section{Gambar 3. Hasil Survei LIPI Tentang Jaminan Sosial Sektor Informal}

Sumber: Data Diolah

Berdasarkan data di atas, dapat ditarik sebuah pemahaman bahwa JKN masih belum merata, bahkan belum sesuai target minimum. Pemahaman yang minim tentang program ini juga terjadi di pedesaan, hal tersebut memerlukan strategi efektif guna memeprluas keberlanjutan program dan minat peserta dalam mengikuti serta mengoptimalkan pelayanan kesehatan bagi pekerja. Dari sudut pandanga JKN, hanya 31,2\% masyarakat yang bergerak dalam usaha sektor informal yang memiliki pengetahuan tentang BPJS Ketenagakerjaan. Faktor penghambat ini diantaranya adalah: 1) Kantor layanan yang sulit dijangkau oleh calon peserta karena jauhnya jarak rumah dan kantor layanan; 2) Tingginya biaya yang harus dikeluarkan; dan 3) bentuk kerjasama dengan penyedia layanan yang sangat minim. Optimalisasi pelayanan melalui teknologi perlu dilakukan dengan baik, melalui seni budaya, peningkatan kerjasama dan inovasi dalam kebijakan juga perlu dilakukan dengan optimal. 
Aspek-aspek yang menghambat realisasi program jaminan sosial bagi pekerja informal ini adalah faktor pendidikan, dan 2) faktor ekonomi. Berdasarkan hasil kuisioner responden, aspek pendidikan responden disajikan dalam tabel berikut ini:

Tabel 1. Pekerja Sektor Informal Responden Berdasarkan Pendidikan

\begin{tabular}{|c|c|c|}
\hline Pendidikan & Jumlah & Persentase \\
\hline Tidak sekolah & 3 & $6 \%$ \\
\hline Tamat Sekolah Dasar & 22 & $44 \%$ \\
\hline Tamat SMP & 15 & $30 \%$ \\
\hline Tamat SMA/SMK & 5 & $10 \%$ \\
\hline Sarjana & 5 & $10 \%$ \\
\hline Total & 50 orang & \\
\hline
\end{tabular}

Sumber: Data Diolah

Berdasarkan data tersebut dapat diketahui bahwa pendidikan rata-rata responden penelitian yang bekerja di sektor informal cenderung rendah, yaitu 44\% responden hanya tamat sekolah dasar. Rendahnya tingkat pendidikan ini sangat berspotensi menjadi hambatan bagi penyelenggaraan program jaminan sosial, karena minimnya akses guna mendapatkan program. Selain itu, kurangnya penyerapan pengetahuan juga menjadi faktor penghambat untuk berkontribusi dalam pekerjaan yang dilakukan serta mengembangkan usahanya. Berdasarkan survei yang dilakukan oleh PISA di Kota Paris menyatakan bahwa pendidikan Indonesia berada di peringkat 72 dari 77 negara. Peringkat enam terbawah ini masih jauh tertinggal dari negara seperti Malaysia dan Brunei Darusallam. Peringkat ini diukur dari tiga faktor utama yaitu kemampuan matematika, kemampuan membaca, dan sains.

Rendahnya kualitas pendidikan ini berpotensi sebagai faktor penghambat implementasi kebijakan pemerintah, karena kualitas pendidikan menggambarkan pemahaman yang menjadi prasyarat implementasi sebuah program yang direncanakan pemerintah. Hal yang perlu dilakukan oleh pemerintah adalah mengoptimalkan sosialisasi bagi pekerja informal. Dari sudut pandang pendapatan responden, hasil kuisioner disajikan dalam tabel berikut:

Tabel 2. Pekerja Sektor Informal Responden Berdasarkan Pendidikan

\begin{tabular}{|c|c|c|}
\hline Income & Jumlah & Persentase \\
\hline$<500.000$ & 3 & $6 \%$ \\
\hline $500.000-1.000 .000$ & 10 & $20 \%$ \\
\hline $1.000 .000-1.500 .000$ & 14 & $28 \%$ \\
\hline $1.500 .000-2.000 .000$ & 11 & $22 \%$ \\
\hline $2.000 .000-2.500 .000$ & 7 & $14 \%$ \\
\hline$>2.500 .000$ & 5 & $10 \%$ \\
\hline Total & 50 orang & \\
\hline
\end{tabular}

Sumber: Data Diolah

Salah satu faktor yang mendorong keikutsertaan pekerja dalam program jaminan sosial adalah faktor pendapatan pekerja. Berdasarkan data di atas, mayoritas responden menyatakan bahwa mereka memiliki pendapatan antara 1.000.000-1.500.000, yaitu 28\% responden. Dan 22\% responden memiliki pendapatan $1.500 .000-2.000 .000$ per bulan. Harapannya, dalam penentuan iuran JSN, pemerintah harus memperhatikan pendapatan pekerja dan memperhitungkan kebutuhan hidup mereka. Menteri Ketenagakerjaan Hanif Dhakiri menyatakan bahwa pemerintah akan menaikan upah para pekerja sektor informal 
sesuai dengan PP No. 78/2015 tenang Pengupahan. Kenaikan sebesar 8,03\% tersebut diharapkan akan membantu para pekerja untuk ikut serta dalam program jaminan sosial yang disosialisasikan oleh Pemerintah. Penentuan upah ini menjadi faktor utama daya tarik antara supply and demand tenaga kerja.

Komitmen pemerintah untuk melaksanakan program jaminan sosial juga dapat diukur dari seberapa besar anggaran yang dialokasikan untuk melaksanakan kebijakan ini. Kementerian Keuangan telah setuju untuk mengalokasikan dana sebesar Rp. 46,77 triliun yang akan digulirkan bagi Penerima Bantuan Iuran, bantuan tersebut didorong untuk memperbaiki akses masyarakat miskin yang tidak mendapat pelayanan kesehatan. Pakar kesehatan menyatakan bahwa premi tidak akan cukup untuk menutupi semua jenis masalah kesehatan, termasuk penyakit katastropik seperti kanker, diabetes, dan talasemia. Lebih jauh lagi, pemerintah akan sulit memaksa rumah sakit swasta untuk mengikuti program kesehatan. dengan alasan karena mereka akan mengharapkan untuk menerima kompensasi yang sesuai untuk layanan mereka. Sebaliknya, para ahli kesehatan ini telah menyatakan bahwa pemerintah harus fokus pada rumah sakit dan pusat kesehatan masyarakat yang dikelola negara untuk memberikan perawatan kesehatan universal. Untuk program ketenagakerjaan, peran pemerintah dalam meng-cover pekerja miskin, terutama di sektor informal, masih hangat diperdebatkan. Masalah iuran pengusaha dan pekerja serta hadiah yang harus dibayar pemerintah untuk pekerja informal miskin belum dibahas.

Faktor lain yang juga sangat berpengaruh adalah faktor kelembagaan atau rumitnya birokrasi, birokrasi yang tidak efisien akan memperlambat proses pemerataan program. Masyarakat cenderung enggan memanfaatkan jamkesmas karena faktor tersebut. Harapannya, pemerintah dapat menciptakan jalur birokrasi yang mudah dan efisein, sebagai contoh dalam program jamkesmas harus dapat memutus lintas sektoral. Peserta jamkesmas hingga kini banyak mengalami kendala dalam pengurusan asuransi kesehatan, maka pemerataan secara luas kepada masyarakat yang tinggal dipedesaan perlu dilakukan dengan efisein, sehingga tidak terdapat sentralisasi jaminan sosial tidak hanya berada di masyarakat pekotaan saja.

\section{Peran dan Implementasi Hukum dalam Memberi Kepastian Jaminan Sosial}

Dalam menyediakan serta membuka lapangan kerja, pekerjaaan dalam sektor informal memiliki peran penting dan sangat signifikan karena dapat menyerap banyak tenaga kerja yang tidak dapat diserap sektor formal sehingga angka pengangguaran tidak meningkat secara signifikan. Dalam masa krisis, pekeraj informal tetap bertahan karena tidak terlalu terpengaruh krisis moneter dan mampu bertahan untuk melindungi perekonomian Indonesia. Penghasilan yang rendah dan tidak menentu, menyebabkan pekerja informal bekerja hanya untuk memenuhi kebutuhan sehari-hari, jarang dari mereka yang meniningkan menjadi peserta jaminan sosial tenaga kerja, padahal di sisi lain pekerja informal membutuhkan perlindungan jaminan sosial ketenagakerjaan, mengingat mereka memiliki risiko yang tinggi dan rentan terhadap kecelakaan kerja.

Dalam UUD 1945 khususnya Pasal 28H ayat (3) disebutkan bahwa "Setiap orang berhak atas jaminan sosial yang memungkinkan berkembangnya dirinya secara utuh bersama manusia yang bermartabat", dan Pasal 34 UUD 1945 amandemen keempat tahun 2002, ayat (1) Orang miskin dan anak terlantar diasuh oleh negara (2) Negara mengembangkan sistem jaringan sosial bagi seluruh rakyat dan memberdayakan masyarakat yang lemah dan tidak 
mampu memenuhi harkat dan martabat kemanusiaan. (3) Negara bertanggung jawab atas penyediaan fasilitas pelayanan kesehatan dan fasilitas pelayanan umum yang memadai. Dengan demikian, negara berkewajiban memberikan perlindungan atau jaminan sosial bagi seluruh rakyatnya.

UU No. 40 tahun 2004 menyatakan bahwa Sistem Jaminan Sosial Nasional menganut prinsip kepesertaan wajib bagi seluruh penduduk di Indonesia. Namun, perluasan kepesertaan dilakukan secara bertahap, dengan mempertimbangkan kondisi anggaran pemerintah, perekonomian, dan masyarakat, serta kesiapan program jaminan sosial. Tahap pertama dimulai dengan pekerja di sektor formal, sedangkan pekerja sektor informal didorong untuk mengikuti program secara sukarela sebagai peserta mandiri. Perpres No. 12 tahun 2013 menyatakan bahwa semua pekerja di sektor informal harus mendaftar ke NHIS paling lambat 1 Januari 2019. Selain itu, Perpres No. 86 tahun 2013 mengatur sanksi administratif untuk mengakses layanan publik seperti paspor, SIM, SIM, kendaraan bermotor, sertifikat tanah, dan izin mendirikan bangunan bagi mereka yang belum terdaftar di NHIS. Namun, sanksi administratif tidak pernah diberlakukan karena alasan politik dan tekanan sosial. Oleh karena itu, hingga saat ini, pekerja di sektor informal masih secara sukarela mendaftar ke NHIS sesuai dengan kebutuhannya sendiri.

Demikian pula dalam Pernyataan Umum HAM tahun 1948 pasal 22 disebutkan bahwa setiap orang berhak atas jaminan sosial sebagai anggota masyarakat. Oleh karena itu, rakyat sebagai warga negara memiliki hak dasar yang melekat untuk mendapatkan pemeliharaan kehidupan oleh negara. Konsekuensinya, negara bertanggung jawab untuk melindungi, melindungi, dan merawat warganya tanpa terkecuali, terutama warga negara yang hidup dalam kemiskinan. Selanjutnya undang-undang Nomor 3 Tahun 1992 tentang Jaminan Sosial Tenaga Kerja menegaskan bahwa Tenaga kerja adalah setiap orang yang dapat melakukan pekerjaan baik di dalam maupun di luar hubungan kerja, untuk menghasilkan barang atau jasa guna memenuhi kebutuhan masyarakat. Namun UU Nomor 3/1992 hanya dapat diimplementasikan bagi tenaga kerja yang bekerja dalam hubungan kerja (pekerja formal), sedangkan tenaga kerja informal dengan jumlah yang lebih besar tidak terlindungi.

Pekerja informal atau bukan penerima upah (BPU) memiliki pekerjaan atau usaha ekonomi secara mandiri untuk memperoleh penghasilan dari kegiatan atau usaha tersebut, yang rentan terhadap kecelakaan kerja dalam pekerjaannya. Pekerja informal, sistem kerja tidak teratur, tidak menggunakan alat keselamatan kerja dan tidak memiliki penjamin seperti yang bekerja di perusahaan atau instansi/lembaga. Lingkungan kerja seringkali tidak menjamin fasilitas keamanan. Area rawan bagi pekerja informal adalah tidak tersedianya peralatan keselamatan yang memadai, sehingga risikonya tentu lebih besar dibandingkan mereka yang bekerja di perusahaan/lembaga atau instansi.

Oleh karena itu, pemerintah perlu memperkuat sektor informal sebagai poin penting karena fakta menunjukkan bahwa sebagian besar pekerja informal masih hidup di garis kemiskinan atau bekerja tetapi miskin. Oleh karena itu, pemerintah perlu memberikan Jaminan Sosial bagi pekerja informal untuk bekerja dengan tenang dan nyaman jika terjadi risiko sosial atau ekonomi dan memastikan bahwa mereka dapat memenuhi kebutuhan dasar, gangguan keuangan, dan menjaga kesejahteraan. Selanjutnya, jaminan sosial adalah hak setiap warga negara yang dilindungi oleh konstitusi; dalam Pasal 41 ayat (1) UU No. 39 
Tahun 1999 tentang HAM, namun pada kenyataannya, tidak semua warga negara memiliki jaminan sosial nasional. Hal ini sesuai dengan amanat Undang-Undang Nomor 40 Tahun 2004 tentang Sistem Jaminan Sosial Nasional dan Undang-Undang Nomor 24 Tahun 2011 tentang Badan Penyelenggara Jaminan Sosial (BPJS); Peran BPJS Ketenagakerjaan sangat jelas untuk melindungi seluruh pekerja, baik formal maupun informal. Perlindungan yang harus diberikan meliputi jaminan kecelakaan kerja (JKK), jaminan hari tua (JHT), jaminan hari tua (JP), dan jaminan kematian (JK).

Pekerja informal umumnya adalah pekerja yang paling rentan terhadap berbagai risiko, dan mereka adalah kelompok yang paling tidak terlindungi. Minimnya informasi membuat pekerja informal tidak memahami pentingnya perlindungan dalam asuransi atau perlindungan jaminan sosial tenaga kerja. Tenaga kerja informal yang mengalami kecelakaan kerja akan semakin terpuruk atau semakin kurang sejahtera karena tidak dapat bekerja dan sangat berdampak pada penghasilannya yang terhenti. Keluarga juga akan merasakan dampak dari terjadinya kecelakaan kerja tersebut. Untuk mengatasi kecelakaan kerja yang mengakibatkan cacat total atau kematian, hari tua, atau pensiun, pekerja harus memperoleh perlindungan hukum atas jaminan sosial tenaga kerja, karena dengan memberikan jaminan sosial ketenagakerjaan, pekerja akan terlindungi sejak pekerja meninggalkan rumah, bekerja, sampai kembali ke rumah. Melalui program ini, pemerintah harus menjamin semua pekerja dalam risiko yang tidak terduga saat melakukan pekerjaan.

\section{KESIMPULAN}

Berdasarkan analisis bahan hukum dan analisis sosiologi, dapat disimpulkan bahwa hukum melindungi kesejahteraan sosial melalui Undang-Undang Nomor 40 tahun 2004 menyatakan bahwa Sistem Jaminan Sosial Nasional menganut prinsip kepesertaan wajib bagi seluruh penduduk di Indonesia. Namun, perluasan kepesertaan dilakukan secara bertahap, dengan mempertimbangkan kondisi anggaran pemerintah, perekonomian, dan masyarakat, serta kesiapan program jaminan sosial. Dalam implementasi kebijakan ini, sektor informal masih mengalami beberapa kendala diantaranya adalah karena faktor pendidikan, faktor ekonomi dan faktor kelembagaan sehingga tingkat partisipasi pekerja cenderung minim dan belum terjadi pemerataan.

\section{DAFTAR PUSTAKA}

Arliman, L. (2017). Perlindungan hukum UMKM dari eksploitasi ekonomi dalam rangka peningkatan kesejahteraan masyarakat. Jurnal Rechts Vinding: Media Pembinaan Hukum Nasional, 6(3), 387-402.

Dartanto, T., Siregar, C. H., Lumbanraja, A. U., Bintara, H., Pramono, W., \& Sholihah, N. K. (2019). Enrolment of Informal Sector Workers on the National Health Insurance System in Indonesia: A Qualitative Analysis. Institute for Economic and Social Research.

Farah, A., \& Yunanto, R. (2016). Pengaturan dan Pelaksanaan Perwalian oleh Lembaga Kesejahteraan Sosial Anak Berdasar Hukum Perdata Indonesia (Studi Kasus di Panti Sosial Asuhan Anak Aisyiyah Semarang). Diponegoro Law Journal, 5(3), 1-11. 
Farianto, W., Samekto, F. A., \& Uwiyono, A. (2018, July). The Informal Sector: Employment Dilema and Solution. In IOP Conference Series: Earth and Environmental Science (Vol. 175, No. 1, p. 012132). IOP Publishing.

Fatoni, M. F., \& Surachman, S. (2019). Analisis Kebijakan Politik Hukum Pemerintah Kota Cilegon atas Peningkatan Kesejahteraan Rakyat Tahun 20102015. IQTISHODUNA, 1(1), 97-114.

Jatmiko, L. (2018). Government Responsibility on Legal Protection to Indonesian Migrant Workers in Informal Sector. JL Pol'y \& Globalization, 79, 156.

Jung, E. (2016). Campaigning for all Indonesians: The politics of healthcare in Indonesia. Contemporary Southeast Asia, 476-494.

Madya, S. D. O., \& Nurwahyuni, A. (2019). Accident Insurance for Informal Sector Workers in Indonesia. Media Kesehatan Politeknik Kesehatan Makassar, 14(1), 95-103.

Pranoto, E. (2018). Pembangunan Sistem Hukum Ekonomi Indonesia Berlandaskan Pada Nilai Pancasila Di Era Globalisasi. Jurnal Spektrum Hukum, 15(1), 89-111.

Priesteta, A. C., Widiowati, D., \& Tukino, T. (2019). Mengintegrasikan Pelayanan Sosial Melalui Pusat Kesejahteraan Sosial (Puskesos) di Kelurahan Dago Kota Bandung. Peksos: Jurnal Ilmiah Pekerjaan Sosial, 18(1).

Pulungan, M. S. (2016). Kebijakan Hukum Otonomi Daerah Dalam Penyelenggaraan Kesejahteraan Sosial (PMKS) Di Provinsi Kalimantan Timur. DiH: Jurnal Ilmu Hukum, 12(24), 102-135.

Riwanto, A., \& Gumbira, S. W. (2017). Politik Hukum Penguatan Fungsi Negara Untuk Kesejahteraan Rakyat (Studi Tentang Konsep Dan Praktik Negara Kesejahteraan Menurut UUD 1945). Jurnal Hukum dan Peradilan, 6(3), 337-360.

Sholihah, I., \& Sabarisman, M. (2018). Pemenuhan Kesejahteraan Sosial Melalui Optimalisasi Ruang Terbuka Hijau (RTH) Di Kawasaan Perkotaan Dalam Perspektif Hukum dan Kebijakan. Sosio Informa, 4(1).

Strijbosch, F. (2019). Informal social security among Moluccan immigrants in the Netherlands. In Between kinship and the state (pp. 169-186). De Gruyter Mouton.

Susanto, S., \& Iqbal, M. (2019). Efektifitas Peranan Hukum dalam Pengelolaan Dana Desa Melalui BUMDes Sebagai Perwujudan Kearifan Lokal yang Berdaya Saing Guna Meningkatkan Kesejahteraan Rakyat. Proceedings Universitas Pamulang, 1(1).

Thoriiq, A. J. (2018). Analisis Yuridis Peran Balai Pemasyarakatan (BAPAS) Terhadap Anak Yang Ditempatkan di Lembaga Penyelenggara Kesejahteraan Sosial (LPKS) (Studi di BAPAS Kelas I Medan).

Widiyastuti, S. (2019). Politik Hukum Badan Usaha Milik Daerah (BUMD) dalam Kegiatan Bisnis untuk Mewujudkan Kesejahteraan Sosial. Jurnal Law and Justice, 4(1).

Widodo, W., \& Galang, T. (2019, October). Poverty, Evictions and Development: Efforts to Build Social Welfare through the Concept of Welfare State in Indonesia. In $3 \mathrm{rd}$ International Conference on Globalization of Law and Local Wisdom (ICGLOW 2019) (pp. 260-263). Atlantis Press.

Zusmelia, Z., Firdaus, F., \& Ansofino, A. (2019). Strengthening strategies of the informal sector in traditional market: an institutional approach. Academic of Strategic Management Journal, 18(3), 1-10. 